\title{
Restricted Heterogeneity of T Cell Receptor Transcripts in Rheumatoid Synovium
}

\author{
William V. Williams, ** Qiong Fang, * Deborah Demarco, ${ }^{3}$ Joan VonFeldt, * Robert B. Zurier," and David B. Weiner 1 \\ *The Rheumatology Section, Department of Medicine, University of Pennsylvania School of Medicine, Philadelphia, Pennsylvania \\ 19104; ${ }^{\ddagger}$ The Rheumatology Section, Children's Hospital of Philadelphia, Philadelphia, Pennsylvania 19104; ${ }^{\S}$ The Rheumatology Section, \\ Department of Medicine, Temple University School of Medicine, Philadelphia, Pennsylvania 19104; "The Rheumatology Division, \\ Department of Medicine, University of Massachusetts School of Medicine, Worcester, Massachusetts 01655; \\ and 'The Wistar Institute, Philadelphia, Pennsylvania 19104
}

\begin{abstract}
RA is characterized by massive proliferation of synovial tissue, accompanying infiltration of the tissue with CD4+ T lymphocytes, and a genetic linkage to the MHC antigen HLA-DR4. Since $\mathrm{T}$ cells are restricted by class II MHC molecules such as DR4, this suggests a direct role for these CD4+ cells in pathogenesis. To investigate $T$ cell receptor (TCR) usage in RA, we used oligonucleotide primers specific for each of the major alpha and beta TCR subfamilies to amplify cDNA derived from whole synovium or synovial tissue $T$ cell lines in a family-specific manner. Detection of amplified DNA was facilitated by utilizing oligonucleotide probes derived from the constant regions of the TCRs. The TCR repertoire present in the synovial $T$ cell lines was quite heterogeneous, with an average of 15 alpha chains and 15.8 beta chains detected. When synovial tissue was analyzed, the predominant TCR subfamilies detected tended to be more restricted, with an average of 4.6 alpha chains and 8.6 beta chains detected. This compared with an average of six alpha chains and 12 beta chains in nonrheumatoid synovial samples. The average percentage of synovia positive per TCR $\beta$ family was significantly lower for RA versus non-RA specimens (46.1 vs $65.6 \%, P=0.034$ ). These findings indicate that while a polyclonal population of $\mathrm{T}$ cells is present in RA synovium, the predominant patterns of TCR transcript expression may be somewhat more restricted, suggesting that TCR-based therapy of RA is possible. (J. Clin. Invest. 1992. 90:326-333.) Key words: rheumatoid arthritis $\bullet T$ cell receptors - polymerase chain reaction • $T$ lymphocytes • autoimmunity
\end{abstract}

\section{Introduction}

Rheumatoid arthritis is characterized pathologically by the proliferation of synovial fibroblast-like and macrophage-like cells, and infiltration of the synovium with lymphocytes, predominantly $T$ cells of the helper (CD4+) phenotype $(1,2)$. Such CD4+ $T$ cells are typically activated by an antigenic peptide complexed with class II MHC molecules (HLA-DR/DP/

Address reprint requests to William V. Williams, M.D., The Rheumatology Section, Department of Medicine, University of Pennsylvania School of Medicine, 570 Maloney, 3600 Spruce Street, Philadelphia, PA 19104. 1992.

Received for publication 30 July 1991 and in revised form 5 March

J. Clin. Invest.

(c) The American Society for Clinical Investigation, Inc.

0021-9738/92/08/0326/08 \$2.00

Volume 90, August 1992, 326-333
DQ). Immunogenetic analysis reveals that RA is associated with HLA-DR4, and more specifically with glutamine/lysine residues at amino acids 70/71 of the HLA-DR $\beta$ chain (3-8). This association is reminiscent of similar associations seen in experimental models of autoimmunity, such as experimental autoimmune encephalomyelitis, a model for multiple sclerosis triggered by autoreactive $\mathrm{T}$ cells reactive to myelin basic protein and specific MHC class II antigens (9-12). The observation of a restriction to certain MHCs in such experimental systems often correlates with a restricted repertoire of $\mathrm{T}$ cell antigen receptors which respond to that $\mathrm{MHC}+$ antigen (13). This has also been documented in multiple sclerosis $\mathrm{T}$ cell lines derived from humans $(14,15)$. In experimental systems, antibodies directed to the relevant $T$ cell receptors, or immunization with peptides derived from these $T$ cell receptors, is capable of ameliorating the disease $(10,11)$. These observations suggest that similar strategies may be applied to human $\mathrm{T}$ cell mediated autoimmune diseases.

Molecular characterization of human $\mathrm{T}$ cell receptors has been greatly aided recently through the application of the polymerase chain reaction (PCR $)^{1}$. By utilizing oligonucleotide primers specific for the different $T$ cell receptor variable region families, family specific amplification is possible (14-16). This technique can be applied to the identification of $T$ cell receptors of interest, as well as aid in the cloning and sequencing of these receptors. The purpose of these studies is to apply PCR with family specific primers to characterize the predominant $T$ cell receptor families present in rheumatoid synovium, with the eventual goal of cloning and sequencing these receptors.

\section{Methods}

Synovial tissue and cell lines. Tissue was obtained at the time of joint surgery and was handled aseptically at all times. The tissue was rinsed in sterile PBS, and placed in a petri dish. The superficial layer snipped off with scissors and minced with a sterile scalpel. The minced tissue was placed in $20 \mathrm{ml}$ PBS with $5 \%$ Hepes buffer, $0.4 \mathrm{~g}$ hyaluronidase (type I-S), $0.04 \mathrm{~g}$ DNA-ase I (type II from bovine pancrease) and $1.2 \mathrm{~g}$ collagenase (type Z) (all from Sigma Chemical Co., St. Louis, MO) with $1 \% \mathrm{FCS}$, and stirred continuously for $90 \mathrm{~min}$ at $37^{\circ} \mathrm{C}$. The large chunks of tissue were decanted, and the cells centrifuged and washed twice in culture media [RPMI 1640 with pen/strep, L-glutamine, sodium pyruvate, nonessential amino acids, Hepes buffer, $5 \times 10^{-5} \mathrm{M}$ $\beta$-mercaptoethanol (all from Gibco Laboratories, Grand Island, NY), and $10 \%$ FCS (HyClone Laboratories, Logan, UT)]. T cells were purified by standard nylon wool chromatography (17), cultured overnight at $1 \times 10^{6} / \mathrm{ml}$ in culture media, and the nonadherent cells were sepa-

1. Abbreviations used in this paper: $\mathrm{PCR}$, polymerase chain reaction; TCR, T cell receptor. 
rated, centrifuged, and maintained in culture. Stimulation of the cells was with either phytohemagglutinin ( $1 \%$ solution, from Sigma), IL-2 (Amgen Biologicals, Thousand Oaks, CA), or media alone. Cells were stimulated for 3-5 d, and then maintained for $1-3 \mathrm{wks}$ in $10 \mathrm{U} / \mathrm{ml} \mathrm{IL-2}$ before analysis.

Fluorescence-activated cell sorter $\left(F A C S^{\otimes}\right)$ analysis. After culture, cells were centrifuged, washed, and resuspended in FACS ${ }^{\circledast}$ media ( $1 \%$ bovine serum albumin in PBS with $0.1 \%$ sodium azide), at $1 \times 10^{6}$ cells per $100 \mu$ l. Primary antibody was added for $20-40 \mathrm{~min}$ on ice. After an additional two washings, the cells were subjected to second antibody (fluorescein isothiocyanate-conjugated goat anti-mouse Ig [Sigma]; at a 1:100 dilution), then washed twice again. The cells were analyzed at the University of Pennsylvania Cancer Center fluorescence activated cell sorter facility. Percent positive was determined by comparing the samples to a no primary antibody control. Antibodies used were OKT3 anti-CD3 (Ortho Diagnostic Systems, Inc., Raritan, NJ), Leu3a anti-CD4 (Becton Dickinson, San Jose, CA), and OKT8 (Ortho), at the dilutions suggested by the suppliers.

$R N A$ extraction and $c D N A$ synthesis. Tissue was homogenized in guanidinium isothiocyanate (GITC) solution, or cells resuspended in GITC solution, and vortexed for $30 \mathrm{~s} .0 .1 \mathrm{ml} 2 \mathrm{M}$ sodium acetate $\mathrm{pH} 4$ was added, the solution vortexed, followed by $1 \mathrm{ml}$ diethylpyrocarbonate (DEP)-water-saturated phenol, the sample mixed, then $0.2 \mathrm{ml} \mathrm{SE}$ VAG, thorough vortexing, and the solution transferred to sterile eppendorf tubes. Each sample was then incubated on ice for $20 \mathrm{~min}$, microfuged for $10 \mathrm{~min}$, and the top layer recovered, RNA precipitated with $2.5 \mathrm{vol}$ of $100 \%$ ethanol and $1 / 10 \mathrm{vol} 1 \mathrm{M}$ sodium acetate $\mathrm{pH} 5.5$ in dry ice/ethanol for $30 \mathrm{~min}$. The solutions were microfuged for 15 min, the supernatant was decanted, the pellets were washed in $70 \%$ ethanol, and rotary evaporated. The dried pellets were resuspended in $50 \mu \mathrm{l}$ DEP-water and RNA quantified spectrophotometrically.
For reverse transcription, $1-20 \mu \mathrm{g}$ of RNA in $10 \mu \mathrm{l}$ was used to synthesize cDNA primed with random hexamers in the following reaction mixture: $3 \mu$ l Maloney Murine Leukemia Virus reverse transcriptase with $6 \mu \mathrm{l} 5 \times$ reverse transcriptase buffer, $1.5 \mu$ l RNAse inhibitor, and $3 \mu \mathrm{l} 0.1 \mathrm{M}$ dithiothreitol (all from Gibco/Bethesda Research Laboratories, Gaithersburg, MD), $3 \mu$ l random hexamers (from Pharmacia LKB Biotechnology, Piscataway, NJ), and either 1 or $3 \mu 1100 \mathrm{mM}$ dNTPs ( $25 \mathrm{mM}$ in each dNTP, from Boehringer Mannheim GmbH, Mannheim, Germany). After a 10 -min preincubation at $25^{\circ} \mathrm{C}$, the reaction was carried out for $1 \mathrm{~h}$ at $42^{\circ} \mathrm{C}$, then $95^{\circ} \mathrm{C}$ for $5 \mathrm{~min}$ followed by storage at $-20^{\circ} \mathrm{C}$ until use.

$P C R$ amplification of $T$ cell receptor variable regions. $\mathrm{cDNA}$ was amplified using the primers listed in Table I, with $\mathrm{V} \alpha / \beta_{\mathrm{n}}$ and $\mathrm{C} \alpha / \beta_{\text {mid }}$ at $0.2 \mathrm{nM}$ concentrations. cDNA was amplified using Taq polymerase and standard reaction conditions suggested by the manufacturer (Perkin-Elmer Cetus Corp., Norwalk, CT). The reaction mixture contained $10 \mu \mathrm{l}$ of $10 \times$ reaction buffer, $16 \mu \mathrm{l} 1.25 \mathrm{mM}$ dNTPs (final concentration $200 \mu \mathrm{M}$ in each dNTP), $5 \mu$ l of each oligonucleotide primer at $20 \mu \mathrm{M}$ (final $1 \mu \mathrm{M}$ in each primer), $5 \mu \mathrm{l}$ of DNA, $0.5 \mu \mathrm{l}$ Taq polymerase, and $58.5 \mathrm{ml}$ distilled/deionized water. Primers were synthesized by the Wistar Institute's oligonucleotide synthesis facility. The program used was DEGEN2, which uses five initial low temperature cycles for low stringency $\left(95^{\circ} \mathrm{C}\right.$ for $1 \mathrm{~min}, 37^{\circ} \mathrm{C}$ for $2 \mathrm{~min}, 52^{\circ} \mathrm{C}$ for $2 \mathrm{~min}$ ), followed by higher stringency for 40 cycles $\left(95^{\circ} \mathrm{C}\right.$ for $1 \mathrm{~min}, 52^{\circ} \mathrm{C}$ for 2 $\min , 72^{\circ} \mathrm{C}$ for $2 \mathrm{~min}$ ), and a final $5-\min 72^{\circ} \mathrm{C}$ elongation phase. For some experiments, the initial 20 cycles of DEGEN2 was used followed by additional increments of five higher stringency cycles $\left(95^{\circ} \mathrm{C}\right.$ for 1 min, $52^{\circ} \mathrm{C}$ for $2 \mathrm{~min}, 72^{\circ} \mathrm{C}$ for $2 \mathrm{~min}$ ), with PCR product removed after each increment of five cycles for analysis. Products were analyzed by electrophoresis on $2-3 \%$ agarose gels stained with ethidium bromide.

TABLE 1 T CELL RECEPTOR PCR PRIMERS

\begin{tabular}{|c|c|c|c|}
\hline Name & Sequence & Name & Sequence \\
\hline$V \alpha 1$ & CTGAGGTGCAACTACTCA & VBI & AAGAGAGAGCAAAAGGAAACATTCTTGAAC \\
\hline $\mathrm{V} \alpha 2$ & GTGTTCCCAGAGGGAGCCATTGCC & VB2 & GCTGCAAGGCCACATACGAGCAAGGCGTCG \\
\hline $\mathrm{V} \alpha 3$ & GGTGAACAGTCAACAGGGAGA & VB3 & AAAATGAAAGAAAAAGGAGATATTCCTGAG \\
\hline $\mathrm{V} \alpha 4$ & ACAAGCATTACTGTACTCCTA & VB4 & CTGAGGCCACATATGAGAGTGGATTTGTCA \\
\hline $\mathrm{V} \alpha 5$ & GGCCCTGAACATTCAGGA & VB5 & CAGAGAAACAAAGGAAACTTCCCTGGTCGA \\
\hline $\mathrm{V} \alpha 6$ & GTCACTTTCTAGCCTGCTGA & VB6 & GGGTGCGGCAGATGACTCAGGGCTGCCCAA \\
\hline $\mathrm{V} \alpha 7$ & AGGAGCCATTGTCCAGATAAA & VB7 & ATAAATGAAAGTGTGCCAAGTCGCTTCTCA \\
\hline $\mathrm{V} \alpha 8$ & GGAGAGAATGTGGAGCAGCATC & VB8 & AACGTTCCGATAGATGATTCAGGGATGCCC \\
\hline $\mathrm{V} \alpha 9$ & ATCTCAGTGCTTGTGATAATA & Vß9 & CATTATAAATGAAACAGTTCCAAATCGCTT \\
\hline $\mathrm{V} \alpha 10$ & ACCCAGCTGGTGGAGCAGAGCCCT & VB10 & CTTATTCAGAAAGCAGAAATAATCAATGAG \\
\hline $\mathrm{V} \alpha 11$ & AGAAAGCAAGGACCAAGTGTT & VB11 & TCCACAGAGAAGGGAGATCTTTCCTCTGAG \\
\hline $\mathrm{V} \alpha 12$ & CAGAAGGTAACTCAAGCGCAGACT & VB12 & GATACTGACAAAGGAGAAGTCTCAGATGGC \\
\hline$V \alpha 13$ & GCTTATGAGAACACTGCGT & VB14 & GTGACTGATAAGGGAGATGTTCCTGAAGGG \\
\hline $\mathrm{V} \alpha 14$ & GCAGCTTCCCTTCCAGCAAT & VB15 & GATATAAACAAAGGAGAGATCTCTGATGGA \\
\hline $\mathrm{V} \alpha 15$ & AGAACCTGACTGCCCAGGAA & VB16 & CATGATAATCTTTATCGACGTGTTATGGGA \\
\hline $\mathrm{V} \alpha 16$ & CATCTCCATGGACTCATATGA & VB17 & TTTCAGAAAGGAGATATAGCTGAAGGGTAC \\
\hline $\mathrm{V} \alpha 17$ & GACTATACTAACAGCATGT & VB18 & GATGAGTCAGGAATGCCAAAGGAACGATTT \\
\hline $\mathrm{V} \alpha 18$ & TGTCAGGCAATGACAAGG & VB19 & CAAGAAACGGAGATGCACAAGAAGCGATTC \\
\hline & & VB20 & ACCGACAGGCTGCAGGCAGGGGCCTCCAGC \\
\hline${ }^{\star} \mathrm{C} \alpha 3^{\prime}$ & AATAGGTCGAGACACTTGTCACTGGA & $\begin{array}{l}{ }^{\star} \mathrm{C} \mathrm{B}_{1} 3^{\prime} \\
{ }^{*} \mathrm{C} \beta_{2} 3^{\prime}\end{array}$ & $\begin{array}{l}\text { CCCTAGCAGGATCTCATAGAGGATGGTGGC } \\
\text { CCCTAGCAAGATCTCATAGAGGATGGTGGC }\end{array}$ \\
\hline${ }^{\star}$ Comid & CTTGTCACTGGATTTAGATCTCTCAGCTG & ${ }^{*} \mathrm{C} \beta$ mid & CTCTGCTTCTGATGGCTCAAACACAGCGAC \\
\hline${ }^{\star} \mathrm{C} \alpha 5^{\prime}$ & GTACACGGCAGGGTCAGGGTTCTGGATATT & $\begin{array}{l}{ }^{\star} \mathrm{C} \mathrm{C}_{1} 5^{\prime} \\
{ }^{\star} \mathrm{C} \mathrm{B}_{2} 5^{\prime}\end{array}$ & $\begin{array}{l}\text { CTCGGGTGGGAACACCTTGTTCAGGTCCTC } \\
\text { CTCGGGTGGGAACACGTTTTTCAGGTCCTC }\end{array}$ \\
\hline
\end{tabular}

${ }^{*}$ Denotes antisense primer. $C B_{1} \& C B_{2}$ primers were used mixed together in equimolar concentrations. 
Transfer and probing. Agarose gels were transferred to nylon filters (Genescreen Plus) by capillary transfer overnight $(18,19)$. Hybridization was with either $\mathrm{C} \alpha 5^{\prime}$ or $\mathrm{C} \beta 5^{\prime}$ primers noted in Table I. Oligonucleotide labeling employed $100 \mathrm{ng}$ DNA, $75 \mu \mathrm{Ci}\left[{ }^{32} \mathrm{P}\right.$ ]ATP, $2.5 \mu \mathrm{l} 10 \times$ kinase buffer ( $500 \mathrm{mM}$ Tris $\mathrm{HCL}$ pH 7.6, $100 \mathrm{mM} \mathrm{MgCl} 2,50 \mathrm{mM}$ dithiothreitol, $1 \mathrm{mM}$ spermadine, $1 \mathrm{mM}$ EDTA), $10 \mathrm{U}$ T4 DNA kinase adjusted to a final volume of $25 \mu \mathrm{l}$ with distilled water. Labeling was carried out by incubation at $37^{\circ} \mathrm{C}$ for $30 \mathrm{~min}$ before use. Blots were prehybridized in $5 \times$ standard saline citrate (SSC), $5 \times$ Denhardt's solution, $0.1 \%$ SDS for $1-1.5 \mathrm{~h}$ at $55^{\circ} \mathrm{C}$ in seal-a-meal bags, most of the solution poured off, ${ }^{32} \mathrm{P}$-labeled oligonucleotide added $(75 \mu \mathrm{Ci})$ and hybridized for $2-3 \mathrm{~h}$ at $42^{\circ} \mathrm{C}$ or overnight at $4^{\circ} \mathrm{C}$, the blots washed once in $2 \times \mathrm{SSC}, 0.1 \% \mathrm{SDS}$ for $20 \mathrm{~min}$ at $45^{\circ} \mathrm{C}$, then three times in $5 \times \mathrm{SSC}$, $0.1 \%$ SDS for $20 \mathrm{~min}$ at $45^{\circ} \mathrm{C}$, and exposed to Kodak XRP film at $-70^{\circ} \mathrm{C}$ for $2-72 \mathrm{~h}$.

Statistics. The standard error of occurrence of each TCR V region family was calculated by the formula:

$100 \sqrt{\frac{p[1-p]}{n}}$

where $n$ is the number of samples analyzed, and $p$ is the proportion of positives. The frequency of occurrence of a particular TCR V region family was considered significantly increased if it was $\geq 2$ standard errors higher than the mean for all $\mathrm{V}$ regions of that type ( $\alpha$ or $\beta$ ). Comparisons of rheumatoid and nonrheumatoid synovial TCR expression employed the Student's $t$ test, with correlations between TCR alpha and TCR beta expression employing $\mathrm{Chi}^{2}$ analysis (20).

\section{Results}

PCR primers. We used primers derived from the human TCR alpha and beta constant regions in conjunction with primers specific for individual variable region families (14-16). The primers used in these studies are listed in Table I, and their relative positions on the coding strand of cDNA indicated in Fig. 1. The constant region primers were designed as antisense primers to allow their use to prime PCR reactions as well as probes for blotting. Variable region primers were designed to act in a family specific manner as has been previously reported (14-16).

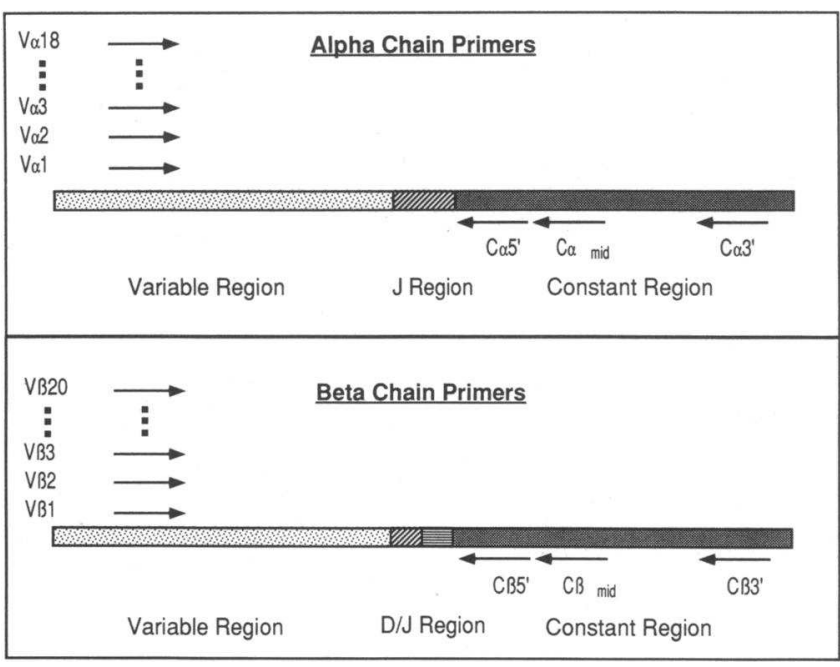

Figure 1. T cell receptor specific oligonucleotides and their relative location. $\rightarrow$ "sense" (coding strand) primer; $\leftarrow$ "antisense" (noncoding strand) primer.
The PCR program used in these studies used a low stringency initial five cycles, followed by 40 cycles at higher stringency. The rationale for using this program was twofold. As these studies were designed to investigate the range of $T$ cell receptors expressed in RA synovium, and all TCR $V$ regions have not yet been sequenced, related TCR families which have sequences related to the primers used here may also be amplified in the initial low stringency cycles. 40 cycles of amplification were then used to amplify even low frequency transcripts. This should help overcome the potential problem of sampling error, which is possible from surgical specimens. Thus, if local accumulations of specific TCR bearing $\mathrm{T}$ cells are present, and such a local accumulation is missed in the surgical specimen, their presence still may be detected if they are also present at lower frequency in the surgical specimen examined. Preliminary experiments with these primers using the DEGEN2 program revealed that all of them (except $\mathrm{V} \beta 16$ ) are effective in amplifying TCR V regions from PHA stimulated peripheral blood mononuclear cells, but that only the appropriate $\mathrm{V}$ region primers amplified Jurkat cell cDNA TCR ([21] and data not shown).

Synovial T cell lines. RNA was extracted and cDNA synthesized from both whole synovium and PHA stimulated synovial $T$ cell lines maintained in IL-2 for 1-2 wk before analysis. Synovial $\mathrm{T}$ cell lines derived in this manner have been previously described (17) and represent a phenotypically mixed population, including CD8+ and CD4+ cells. FACS ${ }^{\circledR}$ analysis was available for four of these cell lines at the time of analysis; data are shown in Table II. In three samples, CD4+ cells predominated, whereas $\mathrm{CD} 8+$ cells were more prevalent in a fourth line.

$T$ cell receptor transcripts were amplified from cDNA derived from these $T$ cell lines. All rheumatoid synovia were obtained at the time of joint surgery, and thus represented late disease. cDNA was split into equal portions and amplified with the middle constant region primers $\left(C \beta_{\text {mid }}\right.$ or $\left.\mathrm{C} \alpha_{\text {mid }}\right)$ in combination with each of the respective individual variable region primers noted in Table I (e.g., $\mathrm{C} \beta_{\text {mid }}+\mathrm{C} \beta 1, \mathrm{C} \beta_{\text {mid }}+\mathrm{C} \beta 2$, . . . $\mathrm{C} \beta_{\text {mid }}+\mathrm{C} \beta 20 ; \mathrm{C} \alpha_{\text {mid }}+\mathrm{C} \alpha 1, \mathrm{C} \alpha_{\text {mid }}+\mathrm{C} \alpha 2, \ldots \mathrm{C} \alpha_{\text {mid }}$ $+\mathrm{C} \alpha 18)$. After electrophoresis and transfer, these were probed with $\mathrm{C} \beta 5^{\prime}$ or $\mathrm{C} \alpha 5^{\prime}$, respectively. Results for the synovial $\mathrm{T}$ cell lines are shown in Fig. 2. An average of 15 alpha chain and 15.8 beta chain families were detected in these cell lines. This suggests that a quite heterogeneous population of $\mathrm{T}$ cells is present in synovium. However, as these cell lines were initially expanded with PHA, it is possible that the proportion of the various TCR subsets alter during culture. In addition, the ability of PHA to activate resting $T$ cells raises concern about the relative proportion of activated $T$ cells following stimulation compared with before stimulation. Therefore, similar analyses

Table II. Phenotype of Synovial Tissue T Cell Lines

\begin{tabular}{|c|c|c|c|c|}
\hline Patient & Control & CD3+ & CD4+ & CD8+ \\
\hline & \multicolumn{4}{|c|}{$\%$} \\
\hline $\mathrm{EP}_{1}$ & 1 & 90 & 25 & 54 \\
\hline $\mathrm{NJ}_{1}$ & 1 & 80 & 81 & 9 \\
\hline $\mathrm{MW}_{1}$ & 1 & 99 & 77 & 28 \\
\hline $\mathrm{HR}_{1}$ & 3 & 98 & 74 & 15 \\
\hline
\end{tabular}



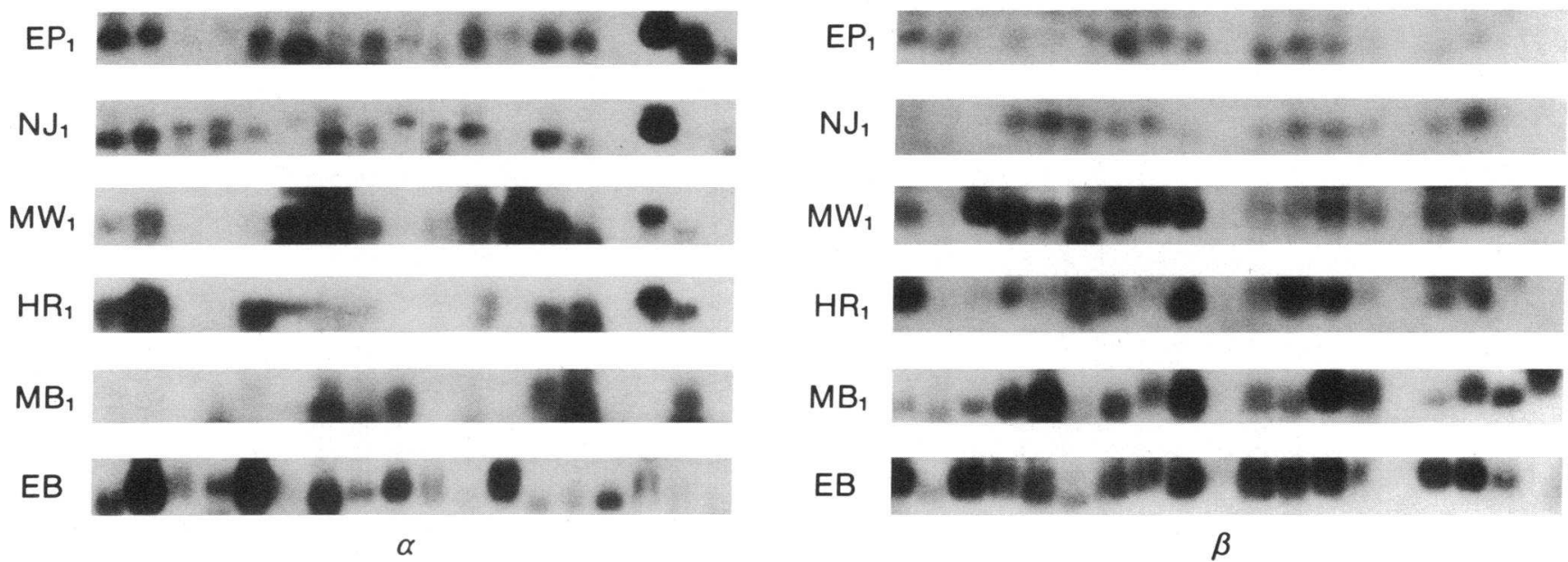

Figure 2. TCR transcripts in RA synovial T cell lines. Rheumatoid synovial T cell lines were developed by initial culture in PHA for 3-5 d, then maintained in IL-2 at $10 \mathrm{U} / \mathrm{ml}$. After 1-3 wk of passage, the cells were frozen, and RNA was later extracted for analysis of TCR expression as outlined in Methods. The sample designations are shown on the left, with the corresponding TCR alpha and beta family-specific primers used indicated above each lane. Note: MB, cells were not PHA-stimulated.

were performed on whole, unstimulated rheumatoid synovium.

Rheumatoid synovium. The results for the whole synovia or freshly isolated, unstimulated synovial $\mathrm{T}$ cells analyzed similarly are shown in Tables III-V. The intensity of the bands detected was quite variable. To further evaluate the technique, cDNA was pooled from four synovia, and amplified with these primers for increasing numbers of cycles (Fig. 3). Note that the intensity of some bands which appeared in early cycles faded relative to the intensity of bands which arose at later cycles. Thus, the intensity of the bands can not be taken as an indicator of the relative abundance of the corresponding cDNA.

The frequency of occurrence of each TCR variable region is tabulated for rheumatoid synovial tissue in Tables III and IV. Similar analysis of nonrheumatoid synovial tissue and synovial fluid is shown in Table V. As the nonrheumatoid samples also included synovial fluid analysis, any comparison of these results assumes that the fluid and tissue $T$ cell receptor repertoires are similar. With this in mind, analysis of Tables III-V reveals that an average of $4.6 \pm 1.64$ alpha chain and $8.4 \pm 1.64$ beta chain families were detected in the rheumatoid synovia studied by this technique. In comparison, an average of $6.0 \pm 2.49$ alpha chain and $11.8 \pm 1.69$ beta chain families were present in the nonrheumatoid synovial tissue and fluid samples examined. When analyzed statistically, the average number of $T$ cell receptor alpha or beta families expressed per rheumatoid synovium did not differ significantly from the average number of $T$ cell receptor alpha or beta families expressed per nonrheumatoid synovial sample (Student's $t$ test).

The average percentage of synovia positive per TCR family

Table III. T Cell Receptor Alpha Chain Expression in 10 Rheumatoid Synovia

\begin{tabular}{|c|c|c|c|c|c|c|c|c|c|c|c|c|c|c|c|c|c|c|c|}
\hline Patient & $\mathrm{V} \alpha 1$ & $\mathrm{~V} \alpha 2$ & $\mathrm{~V} \alpha 3$ & $V_{\alpha 4}$ & $\mathrm{~V} \alpha 5$ & $\mathrm{~V} \alpha 6$ & $\mathrm{~V}_{\alpha} 7$ & $\mathrm{~V} \alpha 8$ & $\mathrm{~V} \alpha 9$ & $V_{\alpha 10}$ & $\mathrm{~V} \alpha 11$ & $\mathrm{~V} \alpha 12$ & $\mathrm{~V} \alpha 13$ & $\mathrm{~V} \alpha 14$ & $\mathrm{~V} \alpha 15$ & $\mathrm{~V} \alpha 16$ & $\mathrm{~V} \alpha 17$ & $\mathrm{~V} \alpha 18$ & Total detected \\
\hline & & & & & & & & & & & & & & & & & & & $n$ \\
\hline MH & + & & & + & + & + & + & + & + & + & & + & + & + & & & + & + & 13 \\
\hline $\mathrm{JL}$ & & & & & & $?$ & & & & & & \pm & & & & & + & & 1 \\
\hline$A G$ & & & & & & & & & & & & & & & & & & & 0 \\
\hline RLP & & & & & & & & & & & & & & & & & & & 0 \\
\hline MG & + & & & + & & & + & & & & + & & & & & & + & & 5 \\
\hline HR & + & & & & & & + & & & & & & & & & & + & & 3 \\
\hline MW & & & & + & & & & & & & & & & + & & & & & 2 \\
\hline MB & & & & & + & + & & + & & & & + & & & & + & + & + & 7 \\
\hline MJ & + & & & & & & & & & & & & & & & & & & 1 \\
\hline & + & + & + & & + & + & + & + & + & + & + & + & & + & + & & + & & 14 \\
\hline Number & & & & & & & & & & & & & & & & & & & $4.6 \pm 1.64^{\ddagger}$ \\
\hline+ & 5 & 1 & 1 & 3 & 3 & 3 & 4 & 3 & 2 & 2 & 2 & 3 & 1 & 3 & 1 & 1 & $6^{*}$ & 2 & $25.6 \pm 3.4 \%$ \\
\hline
\end{tabular}

* $>2$ Standard errors from mean.

$\ddagger$ Average number of TCR $\alpha$ families detected per synovium \pm standard error

Average percentage of synovia positive per TCR $\alpha$ family \pm standard error 


\begin{tabular}{|c|c|c|c|c|c|c|c|c|c|c|c|c|c|c|c|c|c|c|c|}
\hline Patient & $\mathrm{V} \beta 1$ & $\mathrm{~V} \beta 2$ & $\mathrm{~V} \beta 3$ & $V \beta 4$ & $\mathrm{~V}_{\beta 5}$ & $\mathrm{~V} \beta 6$ & $\mathbf{V} \beta 7$ & $\mathrm{~V} \beta 8$ & $\mathrm{~V} \beta 9$ & $v_{\beta 10}$ & $\mathrm{~V} \beta 11$ & $\mathrm{~V} \beta 12$ & $\mathrm{~V} \beta 14$ & $V_{\beta 15}$ & $\mathrm{~V} \beta 17$ & $\mathrm{~V} \beta 18$ & $V_{\beta 19}$ & $\mathrm{~V} \beta 20$ & $\begin{array}{c}\text { Total } \\
\text { detected }\end{array}$ \\
\hline & & & & & & & & & & & & & & & & & & & $n$ \\
\hline MH & + & + & & + & + & + & + & + & + & & + & + & + & & + & + & + & & 14 \\
\hline $\mathrm{JL}$ & & & & & & & + & $?$ & & & + & + & + & + & + & & + & & 7 \\
\hline AG & + & & + & & + & & + & $?$ & & & + & + & + & & + & & + & & 9 \\
\hline RLP & & & & & & & & & & & + & + & & & + & & & & 3 \\
\hline MG & & & + & & + & & + & + & + & + & & + & + & & + & + & & & 10 \\
\hline HR & + & & & + & + & + & + & $?$ & + & $?$ & + & + & + & + & + & & + & & 12 \\
\hline MW & & + & + & + & + & & & + & + & + & + & + & + & + & + & & + & & 13 \\
\hline MB & & & & & & & + & $?$ & & $?$ & & & + & & & & & & 2 \\
\hline MJ & & & & & & & & $?$ & & $?$ & & & & & & & & & 0 \\
\hline EB & + & + & & + & + & + & + & + & + & & & + & + & + & + & + & + & & 14 \\
\hline Number & & & & & & & & & & & & & & & & & & & $8.4 \pm 1.64^{\ddagger}$ \\
\hline+ & 4 & 3 & 3 & 4 & 6 & 3 & 7 & 4 & 5 & 2 & 6 & $8^{*}$ & $8^{*}$ & 4 & $8^{*}$ & 3 & 6 & 0 & $\frac{0.4 \pm 1.04}{46.7 \pm 5.3 \%}$ \\
\hline
\end{tabular}

* $>2$ standard errors from mean.

\# Average number of TCR $\beta$ families detected per synovium \pm standard error

Average percentage of synovia positive per TCR $\beta$ family \pm standard error

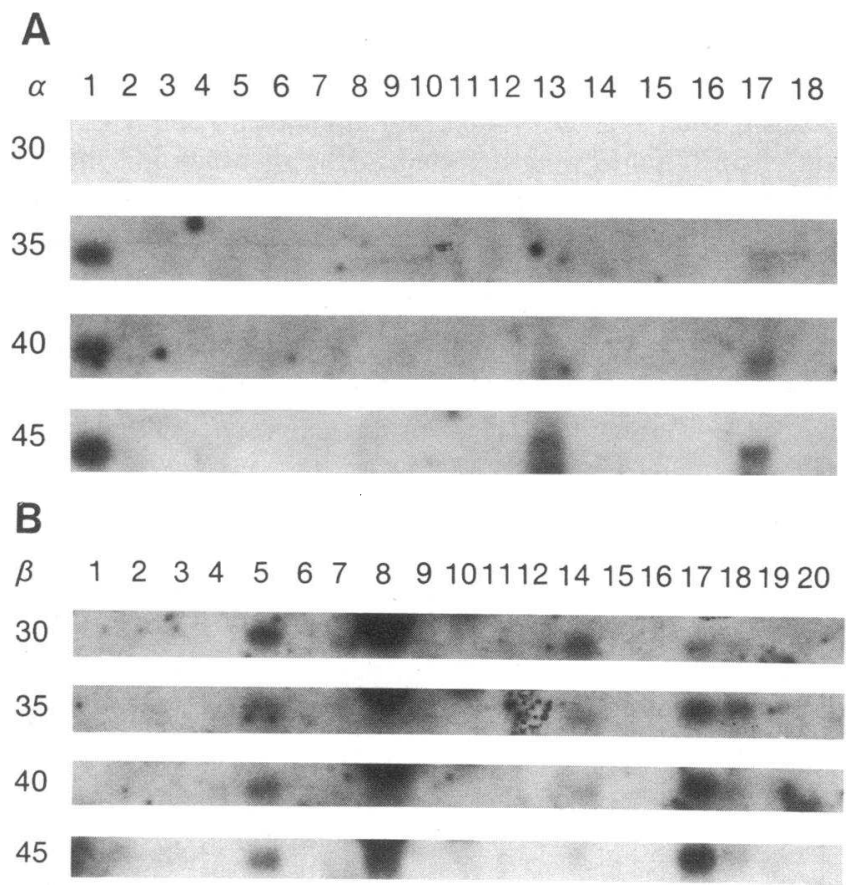

Figure 3. Effect of PCR cycle number on TCR transcripts identified. RNA was extracted and cDNA was synthesized from rheumatoid synovial tissues obtained at the time of joint surgery. $(A)$ Alpha chain primers: cDNA from rheumatoid synovia $\mathrm{MB}, \mathrm{MJ}, \mathrm{AG}$, and $\mathrm{MG}$ were pooled, and aliquots amplified for five low stringency cycles followed by $25,30,35$, or 40 high stringency cycles (corresponding to $30,35,40$, or 45 cycles noted.) Aliquots were removed following each time point, electrophoresed and probed as noted. The $\mathrm{V} \alpha$ family specific primers are shown above each lane. $(B)$ Beta chain primers: cDNA from rheumatoid synovia $\mathrm{MH}, \mathrm{MW}, \mathrm{HR}$, and $\mathrm{JL}$ were pooled, and aliquots amplified for five low stringency cycles followed by 25 , 30,35 , or 40 high stringency cycles (corresponding to $30,35,40$, or 45 cycles noted). Aliquots were removed following each time point, electrophoresed and probed as noted. The $\mathrm{V} \beta$ family specific primers are shown above each lane. may also be compared for rheumatoid versus nonrheumatoid synovia. This should give an indication of the probability that an "average" TCR family would be detected in a collection of synovial samples. In this analysis for the alpha chains there are $25.6 \pm 3.4 \%$ rheumatoid versus $33.3 \pm 5.11 \%$ nonrheumatoid synovia positive per TCR family ( $P=$ not significant, Student's $t$ test). For the beta chain, there are $46.7 \pm 5.3 \%$ rheumatoid versus $65.6 \pm 7.01 \%$ nonrheumatoid synovia positive per TCR family ( $P=0.036$, Student's $t$ test $)$. This indicates that while the number of TCRs detected per synovium was not significantly different for rheumatoid versus nonrheumatoid synovia, the frequency with which any given TCR $\beta$ family was found in the collection of rheumatoid synovia was significantly lower compared with nonrheumatoid synovia.

When the frequency of specific TCR families is analyzed, several rheumatoid TCR families appeared more frequently than others. Specifically, $V \alpha 17$ was present in $6 / 10$ rheumatoid synovia, and $\mathrm{V} \alpha 1$ was present in $5 / 10 . \mathrm{V} \beta 14$ was seen in $8 / 10$ rheumatoid synovia, as were $\mathrm{V} \beta 17$ and $\mathrm{V} \beta 12$, while $\mathrm{V} \beta 7$ was seen in $7 / 10$. The frequency of $V \beta 12,14$, and 17 were $\geq 2$ standard errors above the mean values for all TCR V $\beta$ s detected in rheumatoid synovia, and $\mathrm{V} \alpha 17$ was $\geq 2$ standard errors above the mean values for all TCR V $\alpha$ s detected in rheumatoid synovia. This suggests the presence of these variable regions in rheumatoid synovia from many different patients. However, when nonrheumatoid synovial samples were analyzed similarly, $\mathrm{V} \beta 5,14,17$, and 18 were $\geq 2$ standard errors above the mean values for all TCR V $\beta$ s detected, with none of the alpha chain families significantly higher by this analysis. (Note that these calculations employed the standard error of each TCR family expressed according to the formula in the Methods, not the standard error of the average number of synovial samples expressing given TCR families shown in Tables III-V). Comparison of the rheumatoid and nonrheumatoid synovia by this method indicates that the frequency of expression of $\mathrm{V} \beta 1,2,3,4,5, \& 18$ and $\mathrm{V} \alpha 2$ and 5 in rheumatoid synovia was $\geq 2$ standard errors below that seen in nonrheu- 
Table V. T Cell Receptor Alpha and Beta Chain Expression in Five Nonrheumatoid Synovia

\begin{tabular}{|c|c|c|c|c|c|c|c|c|c|c|c|c|c|c|c|c|c|c|c|}
\hline$\frac{\text { Patient* }}{\text { Dx }}$ & $\mathrm{V} \alpha 1$ & $\mathrm{~V} \alpha 2$ & $\mathrm{~V} \alpha 3$ & $\mathrm{~V} \alpha 4$ & $V_{\alpha} 5$ & $\mathrm{~V} \alpha 6$ & $\mathrm{~V} \alpha \boldsymbol{\gamma}$ & $\mathrm{V} \alpha 8$ & $\mathrm{~V} \alpha 9$ & $\mathrm{~V} \alpha \mathbf{\alpha 1 0}$ & $\mathrm{V}_{\alpha 11}$ & $\mathrm{~V} \alpha 12$ & $\mathrm{~V} \alpha 13$ & $\mathrm{~V} \alpha 14$ & $\mathrm{~V} \alpha 15$ & $\mathrm{~V} \alpha 16$ & $\mathbf{V} \alpha 17$ & $\mathrm{~V} \alpha 18$ & $\begin{array}{c}\text { Total } \\
\text { detected }\end{array}$ \\
\hline & & & & & & & & & & & & & & & & & & & $n$ \\
\hline$\frac{\mathrm{RN}}{\mathrm{DJD}}$ & + & + & & + & + & + & & + & & + & & & & & & & + & + & 9 \\
\hline$\frac{\mathrm{AJ}}{\mathrm{DJD}}$ & + & + & & & + & & & + & & & & & & & & & + & & 5 \\
\hline$\frac{\mathrm{WJ}}{\mathrm{AS}^{\delta}}$ & + & + & + & + & + & & + & + & + & & + & + & + & + & & + & & + & 14 \\
\hline$\frac{\mathrm{JP}^{\ddagger}}{\mathrm{AS}^{\zeta}}$ & & & & & & & & & & & & & & & & & + & & 1 \\
\hline$\frac{\mathrm{JP} 2^{\S}}{\mathrm{AS}}$ & & & & & & & & + & & & & & & & & & & & 1 \\
\hline $\begin{array}{l}\text { Number } \\
+\end{array}$ & 3 & 3 & 1 & 2 & 3 & 1 & 1 & 4 & 1 & 1 & 1 & 1 & 1 & 1 & 0 & 1 & 3 & 2 & $\frac{6.0 \pm 2.49^{1}}{33.3 \pm 5.11 \%}$ \\
\hline & $\mathbf{V} \beta 1$ & $\mathrm{~V}_{\beta 2}$ & $\mathrm{~V} \beta 3$ & $\mathrm{~V} \beta 4$ & $\mathrm{~V} \beta 5$ & $\mathrm{~V} \beta 6$ & $\mathrm{~V} \beta 7$ & $\mathrm{~V} \beta 8$ & $\mathrm{~V} \beta 9$ & $\mathrm{~V} \beta 10$ & $\mathrm{~V} \beta 11$ & $\mathrm{~V} \beta 12$ & $\mathrm{~V} \beta 14$ & $V \beta 15$ & $\mathbf{V} \beta 17$ & $\mathrm{~V} \beta 18$ & $\mathrm{~V} \beta 19$ & $\mathrm{~V} \beta 20$ & $\begin{array}{c}\text { Total } \\
\text { detected }\end{array}$ \\
\hline$\frac{\mathrm{RN}}{\mathrm{DJD}}$ & + & + & & + & + & & & & & & & + & + & & + & + & & & $\begin{array}{l}n \\
8\end{array}$ \\
\hline$\frac{\mathrm{AJ}}{\mathrm{DJD}}$ & + & & + & + & + & & + & $?$ & + & $?$ & + & + & + & & + & + & + & & 12 \\
\hline$\frac{\mathrm{WJ}}{\mathrm{AS^{ \delta }}}$ & + & + & + & + & + & + & + & + & + & & + & + & + & + & + & + & + & & 16 \\
\hline$\frac{\mathrm{JP} 1^{\S}}{\mathrm{AS}}$ & + & + & + & + & + & & + & + & + & + & + & + & + & & + & + & + & & 15 \\
\hline$\frac{\mathrm{JP} 2^{\S}}{\mathrm{AS}}$ & & & & & + & & & + & + & + & + & & + & & + & + & & & 8 \\
\hline $\begin{array}{c}\text { Number } \\
+\end{array}$ & 4 & 3 & 3 & 4 & $5^{\ddagger}$ & 1 & 3 & 3 & 4 & 2 & 4 & 4 & $5^{\ddagger}$ & 1 & $5^{\ddagger}$ & $5^{\ddagger}$ & 3 & 0 & $\frac{11.8 \pm 1.69^{\prime}}{65.6 \pm 7.01 \%}$ \\
\hline
\end{tabular}

* Patient indicated with diagnosis. DJD = degenerative joint disease; AS = ankylosing spondylitis. ${ }^{\ddagger} \mathrm{JP} 1$ and JP2 represent synovial fluid obtained 10 days apart from the same individual. ${ }^{8}$ Synovial fluid used for RNA isolation (all others from synovial tissue). " $>2$ standard errors above mean.

- Average number of TCR $\alpha$ or $\beta$ families detected per synovium \pm standard error

Average percentage of synovia positive per $\alpha$ or $\beta$ TCR family \pm standard error

matoid samples. None of the TCR families were expressed in rheumatoid synovia $\geq 2$ standard errors more frequently than in nonrheumatoid synovia.

\section{Discussion}

Many lines of evidence indicate that $\mathrm{T}$ cells are involved in the development of rheumatoid joint disease. These include the presence of lymphocytic infiltrates composed primarily of CD4+ T cells in the synovium (1, 2, 22-24), the linkage of RA to HLA-DR4 which comprises a ligand for CD4+ T cell receptors (3-8), and experimental models of arthritis and related autoimmune diseases that can be transferred by $\mathrm{T}$ cell lines $(10,12,13,25-34)$. Studies in both animal models and human rheumatoid arthritis indicate that anti-T cell reagents can be of therapeutic efficacy $(10,11,26,35-41)$. However, if these reagents are nonspecific and delete too large a portion of the $T$ cell repertoire, immunodeficiency may result.

A better therapeutic alternative is to delete only those $T$ cells involved in the autoimmune response. Studies of rheumatoid $\mathrm{T}$ cell receptors suggest a polyclonal or oligoclonal population (3, 42-48). These studies generally employed Southern analysis searching for restriction fragment length polymorphisms to determine the oligoclonality of the populations analyzed. Two reports used PCR with family specific primers in analysis of rheumatoid synovial fluid lymphocyte TCRs (46, 49). In analysis of synovial fluid and peripheral blood lymphocytes from three patients with RA, Sottini et al. found evidence for restriction in TCR $\mathrm{V} \beta$ transcripts but not $\mathrm{V} \alpha$ transcripts (46). They suggested a role for $V \beta 7$ in pathogenesis based on 
its occurrence in $2 / 3$ synovial fluids. In a similar analysis which also employed relative quantification of TCR transcripts, Paliard et al. (49) found a relative abundance of $\mathrm{V} \beta 14$ transcripts in synovial fluid with a corresponding decrease in $\mathrm{V} \beta 14$ in peripheral blood from RA patients. These studies indicate that while the $T$ cell population present in rheumatoid synovial fluid is heterogeneous, based on $\mathrm{T}$ cell receptor analysis, that some $\mathrm{T}$ cell receptors are more common than others among the different patients.

The current study confirms some of these observations in RA synovial tissue, while also suggesting additional interpretations based on analysis of nonrheumatoid specimens. Since the synovial tissues described here were all obtained from patients undergoing joint surgery, they all represent long-standing RA. The data presented herein may not be directly applicable to synovial tissue from patients earlier in the disease course. However, in the setting of long standing RA, a polyclonal population might be expected in the synovium. In fact, while the number of TCR $\alpha$ or $\beta$ chain families detected per synovial sample was not significantly less for rheumatoid compared with nonrheumatoid synovial samples, the average number of synovia positive per TCR $\beta$ chain family was significantly less compared with the nonrheumatoid specimens. As the nonrheumatoid specimens also included synovial fluid, these results should be interpreted with caution. However, this does indicate a greater restriction of TCR $\beta$ expression among different rheumatoid synovia compared with the nonrheumatoids. A similar restriction may also exist during earlier stages of rheumatoid pathogenesis.

In addition, predominance of some TCR transcripts was found. Specifically, $\mathrm{V} \alpha 17, \mathrm{~V} \alpha 1, \mathrm{~V} \beta 12, \mathrm{~V} \beta 14, \mathrm{~V} \beta 17$, and $\mathrm{V} \beta 7$ appeared in more than half of the rheumatoid synovial tissue samples studied (Tables III and IV). None of the samples lacked at least one of these $T$ cell receptor chain families. However, some of these same TCR families were also found quite frequently in nonrheumatoid synovial tissue and fluid (Table V). Comparison of the rheumatoid and nonrheumatoid specimens indicates that there is no evidence for an increased frequency of expression of any given TCR alpha or beta family in the rheumatoid synovia. Instead, the frequency of some of the TCR families encountered was $>2$ standard errors decreased for the rheumatoid compared with the nonrheumatoid specimens. This included $\mathrm{V} \alpha 2,5, \& 8$ and $\mathrm{V} \beta 1,2,3,4,5$, and 18 . This suggests that these TCR families are not associated with the rheumatoid synovial lesion.

The high frequency with which $\mathrm{V} \alpha 17, \mathrm{~V} \alpha 1, \mathrm{~V} \beta 12, \mathrm{~V} \beta 14$, $\mathrm{V} \beta 17$, and $\mathrm{V} \beta 7$ occurred compared with other TCR families in the rheumatoid synovia should be interpreted in light of the nonrheumatoid findings. The lower average expression of TCR families in the rheumatoid tissues suggests a greater potential role for those TCRs expressed more frequently. It is interesting to note that $\mathrm{V} \beta 14$ and 17 were also found in $100 \%$ of the nonrheumatoid specimens. The higher average frequency of TCR $\mathrm{V}$ region family expression in the nonrheumatoid specimens makes interpretation difficult, but this may indicate a relative predilection for $\mathrm{T}$ cells bearing these receptors to target synovial tissue as a general phenomenon. Such tissue-specific TCR expression has been reported for gamma-delta $T$ cell receptors (50), but the significance remains unclear.

The potential existence of rheumatoid-specific $T$ cells, possessing a functional alpha-beta TCR pair, can not be discounted. Such a T cell is likely to include at least one TCR chain which is frequently encountered in multiple different rheumatoid synovial specimens. It is interesting to note that in rheumatoid synovia analyzed herein, there was a significant correlation between expression of $\mathrm{V} \alpha 17$ and $\mathrm{V} \beta 14\left(\mathrm{Chi}^{2}\right.$ $=3.75, P=0.05)$. This correlation was not apparent in the nonrheumatoid synovia, or for the other frequently expressed TCR families in the rheumatoid synovia. As these and other TCRs are further characterized the molecular basis for autoreactivity and association with HLA-DR4 may be appreciated. Reagents and therapies designed to specifically target the $T$ cells which bear these $T$ cell receptors should be of use in further delineating the function of these cells, and may be efficacious in ameliorating some of the disease manifestations of rheumatoid arthritis.

\section{Acknowledgments}

We wish to thank Alan Pickard for FACS ${ }^{\circledR}$ analysis and J. Paul for his helpful comments.

R. B. Zurier was supported by grants from the National Institutes of Health (NIH) and Commonwealth of Pennsylvania; D. B. Weiner was supported by grants from the American Foundation for AIDS Research, the Council for Tobacco Research, and the NIH. W. V. Williams was supported by grants from the NIH, the Lupus Foundation, the American Federation for Aging Research, the Scleroderma Federation and Research Foundation, and the Arthritis Foundation, Eastern Pennsylvania Chapter.

\section{References}

1. Firestein, G., and N. Zvaifler. 1987. The pathogenesis of rheumatoid arthritis. In Immunology of Rheumatic Diseases. D. Pisetsky and R. Snyderman, editors. $447-461$.

2. Duke, O., G. S. Panayi, G. Janossy, and L. W. Poulter. 1982. An immunohistological analysis of lymphocyte subpopulations and their microenvironment in the synovial membranes of patients with rheumatoid arthritis using monoclonal antibodies. Clin. Exp. Immunol. 49:22-30.

3. Gao, X., E. Ball, L. Dombrausky, N. Olsen, T. Pincus, M. Kahn, and F. Wolfe. 1988. Class II human leukocyte antigen genes and T cell receptor polymorphisms in patients with rheumatoid arthritis. Am. J. Med. 85:14-16.

4. Goronzy, J., C. M. Weyand, and C. G. Fathman. 1986. Shared T cell recognition sites on human histocompatibility antigen class II molecules of patients with seropositive rheumatoid arthritis. J. Clin. Invest. 77:1042-1049.

5. Gregerson, P., J. Silver, and R. Winchester. 1988. Genetic susceptibility to rheumatoid arthritis and human leukocyte antigen polymorphism. The role of shared conformational determinants. Am. J. Med. 85:17-19.

6. Merryman, P., R. Crapper, S. Lee, P. Gregersen, and R. Winchester. 1989. Class II major histocompatibility complex gene sequences in rheumatoid arthritis. Arthritis Rheum. 32:251-258.

7. Nepom, G., J. Hansen, and B. Nepom. 1987. The molecular basis for HLA class II association with rheumatoid arthritis. J. Clin. Immunol. 7:1-7.

8. Roudier, J., J. Petersen, G. Rhodes, J. Luka, and D. Carson. 1989. Susceptibility to rheumatoid arthritis maps to a T-cell epitope shared by the HLA-Dw4 DR $\beta-1$ chain and the Epstein-Barr virus glycoprotein gp1 10. Proc. Natl. Acad. Sci. USA. 86:5104-5108.

9. Saki, K., A. A. Sinha, D. J. Mitchell, S. S. Zamvil, J. B. Rothbard, H. O. McDevitt, and L. Steinman. 1988. Involvement of distinct murine T-cell receptors in the autoimmune encephalitogenic response to nested epitopes of myelin basic protein. Proc. Natl. Acad. Sci. USA. 85:8608-8612.

10. Hashim, G., A. Vandenbark, A. Galang, T. Diamanduros, E. Carvalho, J. Srinivasan, R. Jones, M. Vainiene, W. Morrison, and H. Offner. 1990. Antibodies specific for $V \beta 8$ receptor peptide suppress experimental autoimmune encephalomyelitis. J. Immunol. 144:4621-4627.

11. Vandenbark, A., G. Hashim, and H. Offner. 1989. Immunization with a synthetic T-cell receptor V-region peptide protects against experimental autoimmune encephalomyelitis. Nature (Lond.). 341:541-544.

12. Beraud, E., T. Resshef, A. A. Vandenbark, H. Offner, R. Friz, C.-H. J. Chou, D. Bernard, and I. R. Cohen. 1986. Experimental autoimmune encephalomyelitis mediated by $\mathrm{T}$ lymphocyte lines: genotype of antigen-presenting cells influences immunodominant epitope of basic protein. J. Immunol. 136:511515.

13. Burns, F. R., X. Li, N. Shen, H. Offner, Y. K. Chou, A. A. Vandenbark, and E. Heber-Katz. 1989. Both rat and mouse $T$ cell receptors specific for the 
encephalitogenic determinant of myelin basic protein use similar $\mathrm{V} \alpha$ and $\mathrm{V} \beta$ chain genes even though the major histocompatibility complex and encephalitogenic determinants being recognized are different. J. Exp. Med. 169:27-39.

14. Oksenberg, J. R., S. Stuart, A. B. Begovich, R. B. Bell, H. A. Erlich, L. Steinman, and C. C. A. Bernard. 1990. Limited heterogeneity of rearranged T-cell receptor $\mathrm{V} \alpha$ transcripts in brains of multiple sclerosis patients. Nature (Lond.). 345:344-346.

15. Wucherpfennig, K. W., K. Ota, N. Endo, J. G. Seidman, A. Rosenzweig, H. L. Weiner, and D. A. Hafler. 1990. Shared human T cell receptor V $\beta$ usage to immunodominant regions of myelin basic protein. Science (Wash. DC). 248:1016-1019.

16. Choi, Y., B. Kotzin, L. Herron, J. Callahan, P. Marrack, and J. Kappler. 1989. Interaction of Staphylococcus aureus toxin "superantigens" with human T cells. Proc. Natl. Acad. Sci. USA. 86:8941-8945.

17. Santoli, D., P. Phillips, T. Colt, and R. Zurier. 1990. Suppression of interleukin-2 dependent human $T$ cell growth in vitro by prostaglandin $E$ (PGE) and their precursor fatty acids in vitro. J. Clin. Invest. 85:424-432.

18. Ausubel, F., R. Brent, R. Kingston, D. Moore, J. Seidman, J. Smith, and K. Struhl. 1989. Current Protocols in Molecular Biology. Greene Publishing Associates and Wiley-Interscience, John Wiley \& Sons, New York. pp. 403-567.

19. Sambrook, J., E. Fritsch, and T. Maniatis. 1989. Molecular Cloning. A Laboratory Manual. Cold Spring Harbor Laboratory Press, Cold Spring Harbor, NY. pp. 73-882.

20. Cooper, B. E. 1969. Statistics for Experimentalists. Pergamon Press, Oxford. $336 \mathrm{pp}$.

21. Williams, W. V., A. Sato, M. Rossman, Q. Fang, and D. B. Weiner. (In press). Semi-random DNA amplification utilizing the polymerase chain reaction. Application to the analysis of antigen receptor variable regions. DNA Cell Biol.

22. Nakao, H., K. Eguchi, A. Kawakami, K. Migita, T. Otsubo, Y. Ueki, C. Shimomura, H. Tezuka, M. Matsunaga, K. Maeda, et al. 1990. Phenotypic characterization of lymphocytes infiltrating synovial tissue from patients with rheumatoid arthritis: analysis of lymphocytes isolated from minced synovial tissue by dual immunofluorescent staining. J. Rheumatol. 17:142-148.

23. Ranki, A., T. Paavonen, E. Tolvanen, U. Kankaanpaa, and P. Hayry. 1984. T lymphocyte subclasses in rheumatoid synovia as analysed with monoclonal antibodies and functional in vitro tests. Scand. J. Rheumatol. 13:67-76.

24. Lapadula, G., M. Covelli, R. Numo, G. Tricarico, G. Amendoni, and C. Berlingerio. 1984. Monoclonal antibody investigation in rheumatoid arthritis: presence of a T cell subpopulation bearing a double marker. Clin. Rheumatol. 3:137-144.

25. Holmdahl, R., L. Klareskog, K. Rubin, E. Larsson, and H. Wigzell. 1985. T lymphocytes in collagen II-induced arthritis in mice. Characterization of arthritogenic collagen II-specific T-cell lines and clones. Scand. J. Immunol. 22:295306.

26. Holoshitz, J., Y. Naparstek, A. Ben-Nun, and I. R. Cohen. 1983. Lines of T lymphocytes induce or vaccinate against autoimmune arthritis. Science (Wash. DC). 219:56-58

27. Holoshitz, J., A. Matitiau, and I. R. Cohen. 1984. Arthritis induced in rats by cloned $\mathrm{T}$ lymphocytes responsive to mycobacteria but not to collagen type II. J. Clin. Invest. 73:211-215.

28. van Eden, W., J. Holoshitz, Z. Nevo, A. Frenkel, A. Klajman, and I. R. Cohen. 1985. Arthritis induced by a T-lymphocyte clone that responds to Mycobacterium tuberculosis and to cartilage proteoglycans. Proc. Natl. Acad. Sci. USA. 82:5117-5120.

29. Yoshino, S., E. Schlipkoter, R. Kinne, T. Hunig, and F. Emmrich. 1990. Suppression and prevention of adjuvant arthritis in rats by a monoclonal antibody to the alpha/beta T cell receptor. Eur. J. Immunol. 20:2805-2808.

30. Clayton, J. P., G. M. Gammon, D. G. Ando, D. H. Kono, L. Hood, and E. E. Sercarz. 1989. Peptide-specific prevention of experimental allergic encephalomyelitis. Neonatal tolerance induced to the dominant $T$ cell determinant of myelin basic protein. J. Exp. Med. 169:1681-1691.

31. Donoso, L. A., C. F. Merryman, T. Shinohara, B. Dietzschold, G. Wistow, C. Craft, W. Morley, and R. T. Henry. 1986. S-antigen: identification of the
MAbA9-C6 monoclonal antibody binding site and the uveitopathogenic sites Curr. Eye. Res. 5:995-1003.

32. Donoso, L. A., C. F. Merryman, T. Shinohara, T. W. Sery, and A. Smith 1987. S-Antigen. Experimental autoimmune uveitis following immunization with a small synthetic peptide. Arch. Ophthalmol. 105:838-843.

33. Lennon, V. A., D. J. McCormick, E. H. Lambert, G. E. Griesmann, and M. Z. Atassi. 1985. Region of peptide 125-147 of acetylcholine receptor alpha subunit is exposed at neuromuscular junction and induces experimental autoimmune myasthenia gravie, T-cell immunity, and modulating autoantibodies. Proc. Natl. Acad. Sci. USA. 82:8805-8809.

34. Williams, W. V., M. Kyriakos, G. C. Sharp, and H. Braley-Mullen. 1987. The cellular basis for the Ia restriction in murine experimental autoimmune thyroiditis. Cell. Immunol. 110:35-45.

35. Walker, C., C. Herzog, P. Rieber, G. Riethmuller, W. Muller, and W. J. Pichler. 1989. Anti-CD4 antibody treatment of patients with rheumatoid arthritis: II. Effect of in vivo treatment on in vitro proliferative response of CD4 cells. $J$. Autoimmun. 2:643-649.

36. Herzog, C., C. Walker, W. Muller, P. Rieber, C. Reiter, G. Riethmuller, P. Wassmer, H. Stockinger, O. Madic, and W. J. Pichler. 1989. Anti-CD4 antibody treatment of patients with rheumatoid arthritis: I. Effect on clinical course and circulating T cells. J. Autoimmun. 2:627-642.

37. Brahn, E., and D. E. Trentham. 1984. Effect of antithymocyte serum on collagen arthritis in rats: evidence that $\mathrm{T}$ cells are involved in its pathogenesis. Cell. Immunol. 86:421-428.

38. Schluesener, H., C. Brunner, K. Vass, and H. Lassmann. 1986. Therapy of rat autoimmune disease by a monoclonal antibody specific for $T$ lymphoblasts. $J$. Immunol. 137:3814-3820.

39. Goldschmidt, T. J., L. Jansson, and R. Holmdahl. 1990. In vivo elimination of $\mathrm{T}$ cells expressing specific $\mathrm{T}$-cell receptor $\mathrm{V}$ beta chains in mice susceptible to collagen-induced arthritis. Immunology. 69:508-514.

40. Kingsley, G. 1991. Monoclonal antibody treatment of rheumatoid arthritis. Br. J. Rheumatol. 2(Suppl.):33-35.

41. Reiter, C., B. Kakavand, E. P. Rieber, M. Schattenkirchner, G. Riethmuller, and K. Kruger. 1991. Treatment of rheumatoid arthritis with monoclonal CD4 antibody M-T151. Clinical results and immunopharmacologic effects in an open study, including repeated administration. Arthritis Rheum. 34:525-536.

42. Van Laar, J. M., A. Miltenburg, M. Verdonk, M. Daha, R. D. Vries, P. V. d. Elsen, and F. Breedveld. 1991. Lack of T cell oligoclonality in enzyme-digested synovial tissue and in synovial fluid in most patients with rheumatoid arthritis. Clin. Exp. Immunol. 83:352-358.

43. Miltenburg, A., J. v. Laar, M. Daha, R. d. Vries, P. v. d. Elsen, and F. Breedveld. 1990. Dominant T-cell receptor beta-chain gene rearrangements indicate clonal expansion in the rheumatoid joint. Scand. J. Immunol. 31:121-126.

44. Duby, A., A. Sinclair, S. Osborne-Lawrence, W. Zeldes, L. Kan, and D. Fox. 1989. Clonal heterogeneity of synovial fluid T lymphocytes from patients with rheumatoid arthritis. Proc. Natl. Acad. Sci. USA. 86:6206-6210.

45. Stamenkovic, I., M. Stegagno, K. A. Wright, S. M. Krane, E. P. Amento, R. B. Colvin, R. J. Duquesnoy, and J. T. Kurnick. 1988. Clonal dominance among T-lymphocyte infiltrates in arthritis. Proc. Natl. Acad. Sci. USA. 85:11791183.

46. Sottini, A., L. Imberti, R. Gorla, R. Cattaneo, and D. Primi. 1991. Restricted expression of $\mathrm{T}$ cell receptor $\mathrm{V}$ beta but not $\mathrm{V}$ alpha genes in rheumatoid arthritis. Eur. J. Immunol. 21:461-466.

47. Savill, C. M., P. J. Delves, D. Kioussis, P. Walker, P. M. Lydyard, B. Colaco, M. Shipley, and I. M. Roitt. 1987. A minority of patients with rheumatoid arthritis show a dominant rearrangement of T-cell receptor beta chain genes in synovial lymphocytes. Scand. J. Immunol. 25:629-635.

48. Stamenkovic, I., M. Stegagno, K. A. Wright, S. M. Krane, E. P. Amento, R. B. Colvin, R. J. Duquesnoy, and J. T. Kurnick. 1988. T lymphocyte infiltrates in inflammatory synovia are oligoclonal. Transplant Proc. 20:315-319.

49. Paliard, X., S. West, J. Lafferty, J. Clements, J. Kappler, P. Marrack, and B. Kotzin. 1991. Evidence for the effects of a superantigen in rheumatoid arthritis. Science (Wash. DC). 253:325-329.

50. Raulet, D. H. 1989. The Structure, function, and molecular genetics of the $\gamma / \delta$ T cell receptor. Annu. Rev. Immunol. 7:175-207. 